\title{
GUEST ESSAY
}

Ed Ikin

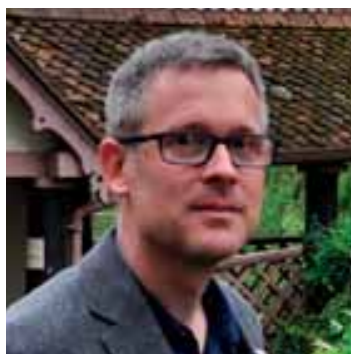

Ed Ikin is Wakehurst Head of Landscape \& Horticulture, curating Royal Botanic Gardens, Kew's 535-acre wild botanic garden in Sussex. Ed trained at Valley and Savill Garden and RHS Wisley and was previously Assistant Head Gardener at Chelsea Physic Garden, Head Gardener at Nymans and General Manager for National Trust London. He has a BSc in Biology and an MA in Garden History, and is Chair of Trustees for London Parks \& Gardens Trust.

\section{THE ART AND SCIENCE OF PLANNING A GARDEN'S FUTURE - WHO SETS THE DIRECTION?}

\section{ABSTRACT}

Successful long-term plans for gardens require creativity and objectivity and need to include the insight of the horticultural teams caring for them. Garden plans take different forms and there are rival schools of thought about the merits of using external consultants or authoring exclusively in house. This essay makes the case for a 'third way', blending the skills of internal and external teams, and shows how the past can inspire the future.

\section{PLANNING THE FUTURE}

A new curator, head gardener or garden manager begins their tenure, heralding 'a new era' for the garden. Soon, they are articulating their vision for the future: the garden's 'next chapter', innovative designs, a fresh take on horticulture. In this febrile atmosphere of change, hearts and minds can be lost, mistakes made and money wasted: the art of creating a successful future plan is not to be underestimated.

Who should write the plan setting out the future of the garden? An in-house plan saves money, reflects the unfettered vision of the curator (and hopefully their team) and is thoroughly grounded in the place. But will it be too parochial and lack external currency when seeking funding and support? Asking a landscape consultancy to produce the plan brings external oversight, glossy production and ambition. But will the garden's voice be lost in graphic design and concept sketches?

Predictably, light and shade exist within these two extremes: the best plans leverage the expertise and objectivity of an external practice and capture the spirit and grain of

1. Ed Ikin is Wakehurst Head of Landscape and Horticulture.

Address: Royal Botanic Gardens, Kew, Wakehurst, Ardingly, Haywards Heath, RH17 6TN, UK.

Email: edikin@kew.org 
the garden, but it requires hard work, open minds and confidence to challenge the status quo.

A generic scenario for commissioning a masterplan stereotypes the consultant as 'expert', and the client (the curator and their team) as 'non-expert', a potentially passive partner. In this hierarchy, content and concepts are generated externally with the risk of appearing alien and ungrounded to the horticultural team when the plan is delivered. A plan which is disconnected from the spirit of the garden, or which appears disrespectful of the past, has every chance, to use a well-worn cliché, of ending up on a shelf gathering dust.

A more sophisticated model depicts the client and consultant as complementary experts. The client team are the guardians of the garden's spirit, purpose and collection; the consultant, an empathetic analyst, editor and facilitator. This duality has historical precedent: great gardens such as Chatsworth and Nymans were forged through a creative, productive axis between owner and artisan. Client-consultant engagement in the creative industries starts with a process known as 'credentials and chemistry'. This explores whether alchemy is possible between parties destined to work together intensively. Chemistry should sit at the heart of a masterplan tender process, with the practitioners who will actually be delivering the plan (as opposed to senior partners who may not) engaged in open and honest conversation with the client team before selection.

Once a consultancy practice has been selected, there should be a commitment to a 'soft' period of discussion, where content, design and scale is collectively iterated; this

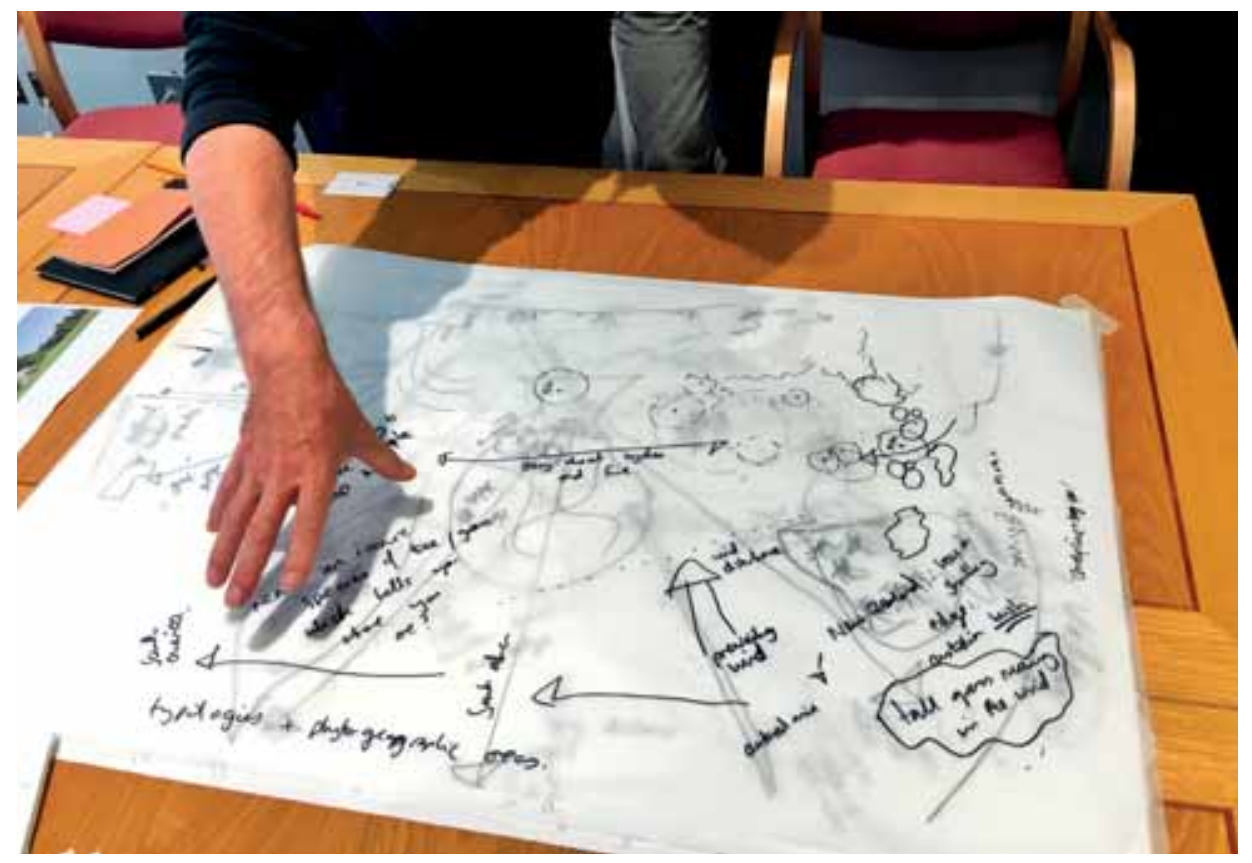

Fig. 1 Discussion and drawings are an essential part of the planning process. Photo: Ed Ikin. 
fosters a sense of joint accountability for the final product. Can the consultant challenge the status quo within the garden without making the horticultural team defensive? Do they understand the 'DNA' of the site and the horticulture that best exemplifies it? Gardens with complex histories or notable plant collections need significant expertise to be analysed, expertise that is not always present in the core team of the landscape practice. Realistic budgets for the cost of bringing horticultural, botanical or historical expertise into the delivery team are essential to guarantee rigour and credibility.

Will the team call the masterplan theirs and plan their work from it? Empathy and respect for the individuals who work hands-on with collections and landscapes is central to a masterplan becoming a purposeful living document. When the horticultural team is placed centrally, as analysts of their site, meaningful answers to questions such as 'Did this design work?' and 'What does horticulture at its best look like here?' can result. Trust underpins this conversation: a thoughtful and humble inception process from the consultants which states 'We want to build on your success' rather than 'Nothing valid has happened here before'. A narrative that captures the team's best ideas and presents them as part of the final plan builds pride and ownership.

\section{THE PAST CAN INSPIRE THE FUTURE}

So much for process, but how are the best new gardens made? I think the past should be an enabler for change, not an impediment. By understanding the motives, constraints, aspirations and frustrations of past owners and curators, the manifest present gains a rich patina of context. It is all too easy to dismiss a sparse planting, a monotonous swathe of ground cover or a traditional island bed planting, but what pressures were the team under at the time? Is it actually a pale imitation of what was planned?

In the hushed atmosphere of an archive, thrilling discoveries can be made: emotive diary entries of the garden owner, confessions of their wildest ambitions for garden making or awe-struck field notes from plant hunters depicting their first view of Chilean bosque siempreverde or Californian giant redwood forest. Even meeting minutes or management reports may, between the lines, reveal aspiration and ambition. What the horticultural investigator is searching for is spirit, that intangible force driving garden owner and garden maker to create often highly personal or deeply subjective content. Some sites develop a 'spirit of place statement', exploring what is distinctive, unique and cherished about their garden. Creating a spirit of place statement can be a creative and inclusive exercise for horticultural teams, although the facilitator should be prepared for strident debate!

With the past as provider of content and context, evaluation of the present becomes informed and emboldened. Every character area can be interrogated with a simple questioning process: 'Does the theme of this area support or detract from the spirit of the site?' and, if the theme is supported, 'Does this area represent the best possible execution of that theme?' From these answers comes the decision to keep or sustain, restore or reinvent. 


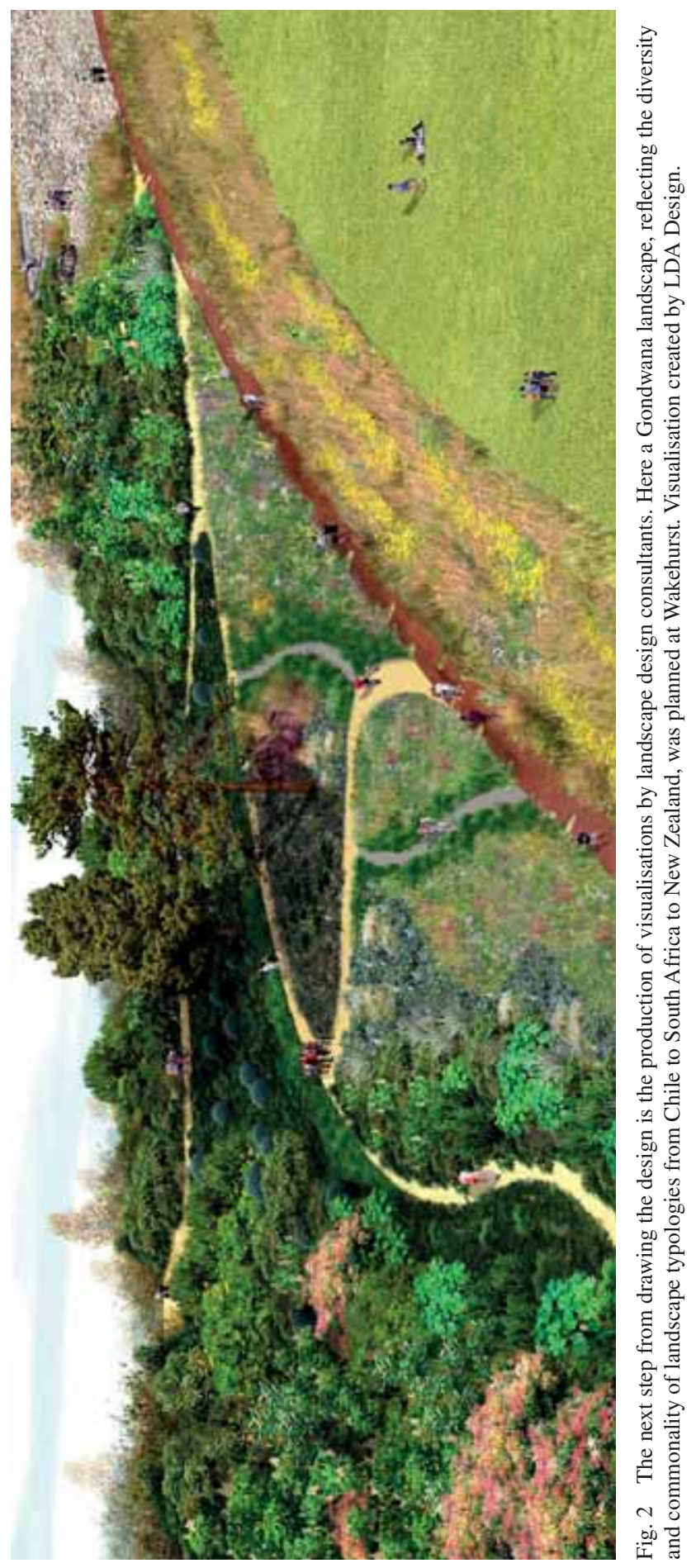


Decisions need to be tempered by statutory constraints such as listings (the allocation of protection of a site by regulations) and the two great environmental challenges of our time: climate change, and exotic pests and diseases. The desire for horticulture that is inherently sustainable and fit for the site without constant inputs should underpin all future planning. A notable rock garden planting, successful in the 1920s, may struggle now without winter wet protection and summer irrigation, so should the original planting be maintained reverentially, taxon by taxon? The original spirit may be gleaned from writings of the time with a particular effect or habitat the creator was seeking to evoke. Returning to these principles may inspire selections of fitter species or even genotypes, which may be more suitable to the current conditions and yet still appropriate to the overarching aesthetic.

Long-term planning provides direction for gardens, an effective framework with which to marshal resources, engage stakeholders and offer the horticultural team a purpose for their work beyond the cyclical patterns of the gardening year. Investing time and money into collaborative, externally facilitated plans can offer a panacea of authenticity and ambition, vision and values. If you've been asked to create a plan, don't see 'getting the consultants in' as the end of your ambitions, but a platform for the best ideas of you, and your team, to thrive.

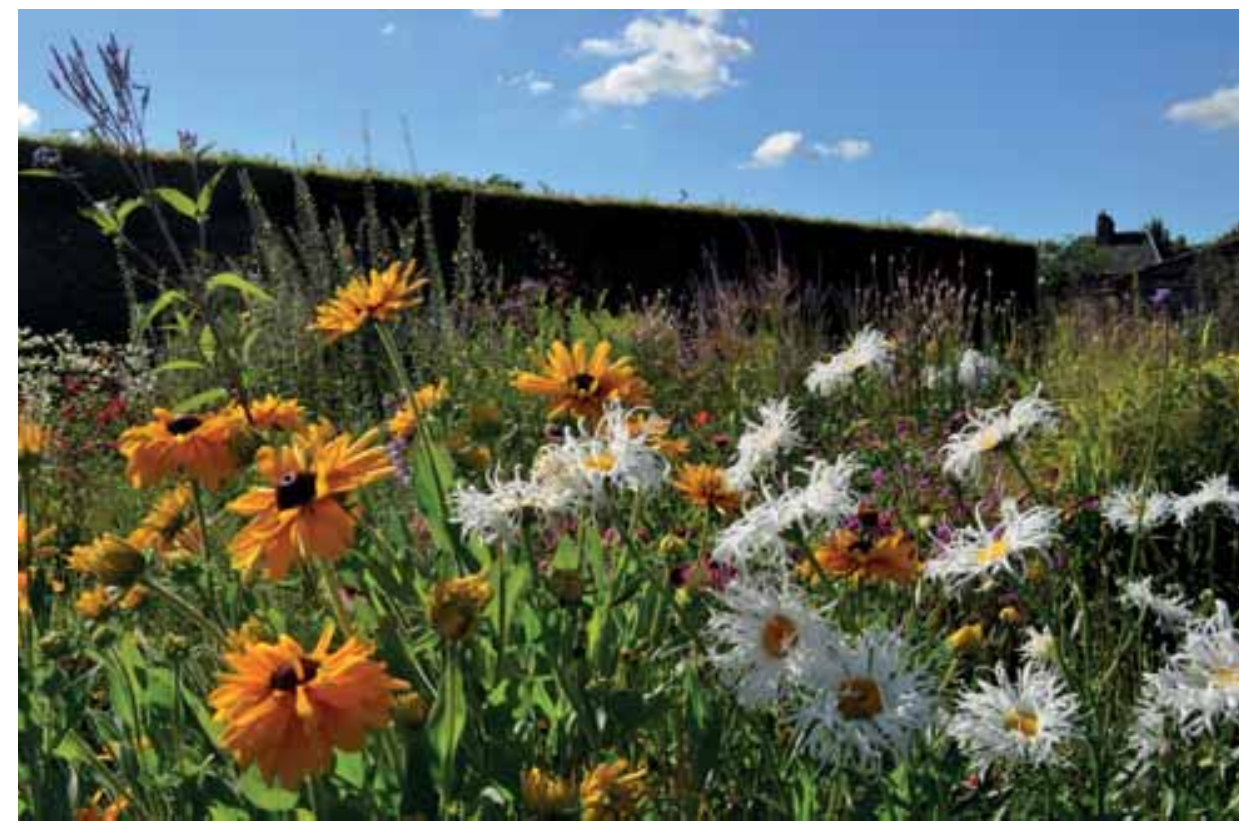

Fig. 3 Le Jardin Plume, Normandy, France: a soulful private garden reflecting the passions and lives of its owners. Photo: Ed Ikin. 